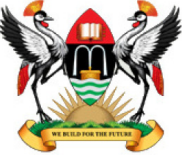

East African School of

Higher Education Studies \& Development
Makerere Journal of Higher Education

ISSN: 1816-6822; 4(1) (2012) $111-124$

DOI: http://dx.doi.org/10.4314/majohe.v4i1.9

(C) The Author(s) 2012

Reprints \& permission: EASHESD

http://ajol.info/majohe

\title{
Perceived Quality of Infrastructure in Selected Nigerian Universities
}

\author{
Subair, S. Tayo ${ }^{1}$, Okotoni, Comfort A. ${ }^{1}$, Adebakin, Azeez, B. ${ }^{1 *}$ \\ ${ }^{1}$ Obafemi Awolowo University [*Corresponding author. E-mail: adebakinazeez@yahoo.com]
}

\begin{abstract}
This study investigated the place of infrastructure in maintaining quality in Nigerian universities. Using a 20-item self designed questionnaire and Available Infrastructure Checklist (AIC), data were collected from a random sample of 800 final year students drawn from federal (300) and state (500) universities in the country. The data were analysed using the t-test statistic and descriptive statistics. It was found that there is no significant difference in infrastructural development between the state and federal universities. Thus, it is recommended that government increases funding towards development of the infrastructure. It is also recommended that universities adhere to appropriate standards of infrastructure maintenance and enrol only those students for whom they have adequate facilities.
\end{abstract}

Keywords: Management of educational resources, Quality assurance

\section{$1 \quad$ Introduction}

Education has for long been recognized as a panacea for nations' ills. This is especially true of higher education. A good higher education system is required for the overall prosperity of a nation. However, in Nigeria, tremendous growth in the higher education sector has made the administration of higher education institutions complex. As the pinnacle of the educational pyramid, the country's universities have critical capacity building roles to play. Greater attention is being focused on quality assurance as a critical factor in ensuring educational relevance. Cabal (Oni and Alade, 2010) posits that the objectives or goals of establishing a university differ from one society to another. Generally, it is a basic assumption that universities are, by definition and long established tradition, meant to be places where all learning activities are governed by creative scepticism, constant questioning, disputations and argumentation. The 
National Policy on Education (2004) relates the relevance of higher education to:

- contributing to national development through training high level manpower;

- developing and inculcating proper values for the survival of the individual and society;

- developing the intellectual capability of individuals to understand and appreciate their local and external environments;

- acquiring both physical and intellectual skills which will enable individuals to be self-reliant and useful members of the society;

- promoting scholarship and community service;

- fostering national unity; and

- promoting national and international understanding and interaction.

Overshooting the carrying capacity of most Nigerian universities is foiling the realization of these objectives. Adedipe (2007) described carrying capacity as the maximum number of students that a university can sustain for quality education based on its human and material resources. Therefore, infrastructure is among the important operational inputs into any instructional programme. It constitutes elements that are necessary for teaching and learning; and is vital in the development of qualitative university education. Ejiogu (1997) noted four important factors in an attempt to balance the qualitative and quantitative growth of the education system in Nigeria. These range from the quality and number of infrastructure (in forms of buildings, machinery and equipment) through the usage to maintenance of the infrastructure. Okebukola (2005) pointed out that the stress put on the universities in terms of demand and the limited expansion in physical facilities and academic staff to cater for this demand has taken a great toll on the quality of programmes in the institutions. Subair (2011) thus submitted that the quality of output (graduates) is a function of infrastructure that determines the students' learning environment and their motivation to learn. Therefore, if quality is to be ensured in the nation's universities, the infrastructural base of the system needs to be improved upon.

\subsection{Problem}

Studies have reported that infrastructural resources required for production of effective education process is in short supply in Nigerian universities. Lecture halls, laboratories, students' hostels, library spaces are grossly inadequate. The available few are fast dilapidating. National Universities Commission (2004) in the communique of the presidential visitation panel that looked into the operations of federal universities between 1999 and 2003 reported that physical 
facilities at the universities were in deplorable condition. It is saddening to note that the equipment for research, teaching and learning are either lacking or very inadequate and in a bad shape to permit the universities the freedom of embarking on the basic functions of academics. There are no facilities for effective practical learning for the students in most courses, especially in the universities of Technology, which require a lot of intensive training in terms of students' usage of their psychomotor skills and hi-tech equipment. In fact, when universities face the NUC accreditation exercise, it is shameful to observe that in order to scale through the hurdles of the exercise, some departments will have to borrow equipment from neighbouring and sister institutions, present them and claim their ownership. With the remarkable increase in the number of universities and university enrolments, it becomes worrisome that the tremendous increase in placement may not correspond to the state of available physical infrastructure. By implication, Nigerian universities are under the siege of decay. To this end, this paper is considered relevant to find out the impact of the infrastructural conditions on quality assurance in Nigerian universities and to also see the workability of some innovative approaches in maintaining the available few infrastructure facilities.

\subsection{Questions}

1. What is the level of infrastructural development between the federal and state universities?

2. How do students rank the available infrastructure in the Nigerian universities?

3. Is there any maintenance culture put in place for the available infrastructure in the universities?

\subsection{Hypothesis}

There is no significant difference in the level of infrastructural development between federal and state universities.

\section{Review of Related Literature}

\subsection{Definition of Infrastructure}

A survey of literature shows that several concepts have been used to explain infrastructure. Among such concepts are the "school plant", "learning resources", "physical resources" and "educational resources", to mention but a 
few (Subair, 2008; Ehiametalor, 2001). In specific terms, Ehiametalor (2001) described infrastructure as the operational inputs of every instructional programme and constitutes elements that are necessary for teaching and learning. Such include buildings, laboratories, machinery, furniture and electrical fixtures. These must be functional in relation to other aspects of the community, such as health centres, libraries, and good roads and must be large enough to allow for expansion as enrolments expand. In the same vein, Osagie (2003) opines that infrastructure represents the aesthetic picture of the school conveyed by the position of structures in relation to one another. It also represents the empirical relevance of the totality of the school environment for the realization of the school business (teaching/learning). He asserted in specific terms that school plant is made up of landscape, trees, lawns, hedges, and accompanying paths, playgrounds, buildings, security facilities and utilities. However, a well-equipped and well-maintained physical plant can make learning a more pleasant experience and discourage early drop-outs. It can as well attract better quality teachers. In summary therefore, infrastructure can be viewed as the totality of all that goes into education such as classrooms, lecture theatres, laboratories, libraries, electricity, water, health centre, sports and recreation centres, ICT, machines and furniture put there-in, with the intention of facilitating teaching-learning.

\subsection{Quality Assurance and its Process in University Education}

Many definitions of quality in education exist, testifying to its complexity and multifaceted nature. It is a multidimensional concept, which encompasses all the functions and activities in schools. Arikewuyo (Adegbesan, 2011) views quality as what could be judged by both its ability to enable students to perform well in standard examinations and relevance to the needs of students, community, and the society as a whole. He concluded that quality serves as determination of graduation based on standard of excellence beneath which a mark of inferiority is imposed and above which grades of superiority are defined. Similarly, quality assurance in the university system implies the ability of the institutions to meet the expectations of the users of manpower in relation to the skills acquired by their outputs (Ajayi and Akindutire, 2007). Therefore, quality education can be an improvement on all aspects of learning and ensuring excellence so that recognizable learning outcomes are achieved by all learners, especially in literacy, numeracy and essential life skills. In other words, quality education should provide learners with essential skills necessary for wholesome development and responsible living.

Assuring the quality of education provision is a fundamental aspect of gaining and maintaining the credibility of higher education programmes, institutions and systems worldwide. Quality assurance is designed to prove and 
improve the quality of an institution's educational methods; and outcomes. In a similar view, Alele-Williams (2004) defines quality assurance in any educational institution as that which indicates the pre-eminence and special features that make the institution distinct from other institutions.

Consequent to the 2004 report of the National Universities Commission (NUC), a university regulatory body in Nigeria, on the universalization of quality assurance in higher education, universities were ranked in terms of their productive functions and relative efforts on their product. In this report, no African university was among the first 200 across the globe. Since this development, the NUC has heightened its efforts in standardizing the quality of university education in Nigeria. According to Adedipe (Oyebade, Oladipo and Adetoro, 2007), the universities and the NUC have a shared onus in addressing the following key areas that are relevant to establishment and maintenance of quality, which are:

- Minimum academic standard

- Accreditation

- Carrying capacity and admission quota

- Visitation

- Impact assessment

- Research and development

- Publications and research assessment

- Structures, infrastructures and utilities

Within institutions of higher learning, use of external examiners, selfevaluation and academic audits are the most common forms of quality assurance processes. Institutions readily accept self-assessment because it empowers them and their staff to take charge of the quality of their performance without the pressure usually associated with external reviews. Self-assessment also helps institutions to identify their own strengths and weaknesses, while generating awareness of key performance indicators. As noted above, it is the process of self-assessment that is widely seen as the most valuable aspect of quality assurance processes. The capacity-building function of self-assessment is particularly important in Nigeria where it remains imperative. Quality assurance therefore serves a variety of purposes but primarily is the effort to ensure credibility and improvement (Oderinde, 2004; Okebukola, 2010).

\subsection{Infrastructure and Quality of University Education in Nigeria}

Qualitative university education constitutes the pivot on which the development of any nation is based. Therefore, proper and correct acquisition of knowledge by the citizens of any nation is fundamental to its growth and development. The 
need for infrastructural support was highlighted by Benya (2001) and Subair (2008) who said, high quality university education and training requires that appropriate infrastructure be provided by the institution. All students deserve safe, technology-ready facilities designed for learning and adequate decent facilities, structured around their learning needs. More importantly, completion rate and satisfaction with the university programmes are closely related to the infrastructure that can be provided. School buildings that can adequately provide a good learning environment are essential for students' success. The bridge between good infrastructure and effective student learning is of great importance. Looking closely at a university system, there is no doubt that infrastructure play a great role in the welfare of students and the result is motivation to learning.

\subsection{Infrastructure and other Dimensions of Quality}

The quality of buildings may be related to other institutional quality issues, such as the presence of adequate instructional materials and textbooks, learning-teaching conditions for students and teachers, and the ability of teachers to undertake certain instructional approaches. Such factors as on-site availability of lavatories and a clean water supply, classroom maintenance, availability of space and furniture, all have an impact on the meaningful learning. Quality assurance of the institutional facilities can only be guaranteed if basic conditions and guidelines are followed from the onset. Basically, this means that infrastructural development must make provision for adaptability or alteration probability, flexibility in user demands, accessibility to students, staff and society and due regards for aesthetic and clean environment. Salis (2002) developed a quality indicator checklist which shows what the physical environment and facilities in higher educational institutions must require both in qualitative and quantitative terms. These include availability of infrastructural development programmes (facility provision), adequacy of the facilities in terms of currency and relevance to purpose; students friendliness and centeredness of the facilities (attractive to students and suitable for their needs); regular maintenance and renewal of the dilapidated ones; the infrastructural development must be of international standard (globally acceptable) to attract foreign students, staff and recognition; and must be environmentally safe and of high sanitary standard.

\section{$3 \quad$ Methodology}

A descriptive survey design was adopted for this study. All universities in south-west Nigeria formed the population of study. After due consideration for 
ownership and curriculum statuses, four universities, two federal (Obafemi Awolowo University, Ile-Ife and University of Lagos, Akoka) and two states (Osun State University, Osogbo and Lagos State University, Ojo) were selected for the study. The subjects included 300 and 500 randomly selected final year students from federal and state universities respectively, giving a total of 800 sample size. The distribution is presented in Table 1.

Table 1: Distribution of Respondents by Institution and Faculty

\begin{tabular}{llll}
\hline \multirow{2}{*}{ Institution } & \multirow{2}{*}{ Ownership } & \multicolumn{2}{c}{ Faculties } \\
& & Engineering & Sciences \\
\hline University of Lagos & Federal & 75 & 75 \\
Obafemi Awolowo University & Federal & 75 & 75 \\
Lagos State University & State & 125 & 125 \\
Osun State University & State & 125 & 125 \\
Total & & 400 & 400 \\
\hline
\end{tabular}

Justification for this selection was based on the level of maturity and independent mind the student would have attained. Two faculties (engineering and sciences) were used for this study. Their selection was based on their need for infrastructure and other materials capable of enhancing technology-driven national development. The multistage, cluster and simple random sampling techniques were adopted to select the chosen number of respondents. A 20 item self designed questionnaire titled "Infrastructure and Quality Assurance Questionnaire (IQAQ)" and available Infrastructure Checklist were used for data gathering. To determine the reliability, the Pearson Product Moment Correlation statistic was applied and a correlation index of .76 (Cronbach's Alpha) was obtained. Descriptive statistic was used to answer the research questions and t-test was used to test the hypothesis at the .05 level of significance.

\section{$4 \quad$ Findings}

\subsection{Level of Infrastructural Development}

Table 2: Availability of Infrastructure in Nigerian Universities $(n=800)$

\begin{tabular}{lll}
\hline Items & Mean SD \\
\hline My university has enough classrooms and well equipped laboratories & 2.07 & 0.67 \\
I enjoy recent books, journals (print \& electronic) in my school library & 3.09 & 0.71 \\
I am taught by seasoned lecturers with relevant teaching aids & $3.46^{*}$ & 0.72 \\
My university has adequate ICT facilities & 1.84 & 0.87 \\
University offers accommodation with reliable power and water supply & 2.09 & 0.69 \\
\hline
\end{tabular}


Table 2 shows the mean values of available infrastructure in the sampled universities. Most students disagree that adequate infrastructure are available in the universities. However, they are cognizant of the fact that academics who form part of university human resources are putting in their best to ensure effective teaching-learning activities despite the hostile working environment. This is evident from the highest mean score of 3.46 and 1.84 to show the hostility of working environment. Therefore, it can be inferred that there are inadequate infrastructure in the universities.

\subsection{Students' Ranking of the Infrastructure in their Universities}

Table 3: Ranking of Available Infrastructure in the Federal and State Universities

\begin{tabular}{lllllll}
\hline \multirow{2}{*}{ Items } & \multicolumn{3}{l}{ Federal Universities $(\mathrm{N}=300)$} & \multicolumn{3}{c}{ State Universities $(\mathbf{N}=500)$} \\
& Mean & SD & Rank & Mean & SD & Rank \\
\hline Libraries & $4.95^{*}$ & 0.94 & 1 & 2.51 & 0.25 & 2 \\
Electricity/water supply & 3.53 & 0.76 & 2 & $4.98^{*}$ & 1.42 & 4 \\
Buildings/furniture & 3.33 & 0.32 & 3 & 2.76 & 1.33 & 3 \\
Laboratories/workshops & 1.70 & 1.34 & 4 & 3.42 & 0.63 & 1 \\
Toilet facilities & 1.58 & 1.37 & 5 & 1.33 & 1.02 & 5 \\
\hline
\end{tabular}

Table 3 shows the mean ranking of available infrastructure in federal and state universities. As indicated above, students from both Federal and State Universities ranked toilet facilities as the least item affecting their learning. However, students in federal universities ranked libraries, electricity/water supply, and buildings/furniture as numbers 1, 2 and 3 respectively as affecting their learning directly whereas; laboratories/workshops and toilet facilities were ranked numbers 4 and 5 respectively as having least significant effect on learning activities. On the other hand, students from state universities ranked laboratories/workshops, libraries and buildings/furniture as numbers 1, 2 and 3 respectively as affecting their learning activities. Also, electricity/water supply and toilet facilities were ranked 4 and 5 as having least effect on learning. Further analysis of the data shows that libraries, electricity/water supply, and buildings/furniture have comparatively higher mean scores of $4.95 ; 3.53$ and 3.33 when compared with mean scores of $3.42 ; 2.51$ and 2.76 obtained for libraries, electricity/water supply, and buildings/ furniture from federal and state universities as having effect on students' learning. Again, laboratories/ workshops has the highest mean scores of (4.98) in state universities with toilet facilities having the lowest mean scores of 1.33; while libraries has the highest mean scores (4.95) and toilet facilities, with 1.58 has the lowest mean score in federal universities. 


\subsection{Culture of Maintaining University Infrastructure}

Table 4: Maintenance of University Infrastructural Facilities $(\mathrm{n}=\mathbf{8 0 0})$

\begin{tabular}{lll}
\hline Items & Mean & SD \\
\hline Teaching equipment are obsolete and need adequate maintenance & 1.86 & 0.68 \\
Facilities are regularly monitored and maintained & 2.70 & 0.79 \\
There is frequent inspection of laboratory equipment & 3.45 & 0.57 \\
Dilapidated structures are adequately repaired & 2.45 & 0.81 \\
Obsolete library materials are frequently replaced & 2.55 & 0.74 \\
\hline
\end{tabular}

Table 4 shows the mean scores on the level of maintenance on universities' infrastructural facilities. Students agreed that existing equipment for teaching and research are obsolete and need adequate maintenance $($ mean $=1.86,2.55)$. By implications, there is no good maintenance practice put in place for the available infrastructure in the universities.

\subsection{Test of Hypothesis}

The hypothesis stated that there is no significant difference in the level of infrastructural development between federal and state universities. It is evident from Table 5 that there is no significant difference in the level of infrastructural development between state and federal universities.

Table 5: Differences in level of Infrastructural development

\begin{tabular}{llllll}
\hline University Type & Mean & SD & N & T-Value & T-Critical \\
\hline State & 14.68 & 2.407 & 800 & 2.309 & 1.960 \\
Federal & 14.31 & 1.874 & & & \\
\hline
\end{tabular}

*Significant, $d f=798, P=.05$

This finding is not surprising because the situation in both state and federal universities appears to be the same. Without adequate physical facilities, one begins to wonder how effective teaching and learning will take place. Consequently, quality is also at stake. For quality university education to be realized, the essential infrastructure must be available in required quantity and quality.

\section{Discussion}

The results obtained revealed that the quality as well as quantity of infrastructure in Nigerian universities is relatively low and inadequate. Most of the facilities (where available) are in very poor condition that suggests poor maintenance practice. For example, the results obtained from observation 
schedule revealed that the federal universities within the scope of this study were found to be more endowed in terms of physical infrastructure, where most of the structures are storey buildings. The ranking of available infrastructure by students showed that libraries, laboratories, classroom blocks and furniture plus electricity and water supply were those items having significant effect on students' learning. Summarily, there is no significant difference in the level of infrastructural development in federal and state universities. This means facilities available in the universities, be it federal or state owned, did not commensurate with the students' population. The resultant effect of which was overstretching of the available ones thereby reduces the life-span. Interestingly, the need for expansion in terms of infrastructure particularly buildings is being recognized. These findings are in agreement with Osagie (2003) who posited that the type and quality of education that students receive bears a direct relevance to the physical facilities provided. Subair (2011, 2008); Nwagwu (2004) and Osagie (2003) submitted that availability of adequate school buildings, classrooms, chairs and tables, laboratory, library and other physical structures are necessary for the accomplishment of any educational goals and objectives and to put the Nigerian universities in a better position to face the challenges of global competition.

To this, the researchers are of the opinion that it is pertinent, therefore, to note that provision of these equipment and materials are essential for effective teaching-learning in the nation's universities which if not available or inadequate will cause adverse effects on the students' learning. It is pathetic to find students studying science and engineering related courses under condition of inadequate facilities to practice with or work on. How then do we pursue the national aims and objectives on education? How then do we attain our dreams of greater height in terms of scientific and technological development? Hence, university structures, libraries, laboratories, workshops, equipment, and so on, should be made available not only to facilitate learning but also making it quality imperative.

The view expressed above is consistent with Dahunsi (2007) who said that all public universities in Nigeria cried of underfunding, the effect of which is evident on the institutions. Numerous abandoned projects, acute shortage of qualify staff, and inadequacy of laboratory, library, teaching and infrastructure among others are regular features of these institutions. The cumulative effect of this is an off-mandate activities and production of graduate described as halfbaked.

\subsection{Implications for Educational Administrators and Planners}

Arising from the findings are a few practical implications for educational administrators and planners as well. It is expected that administrators and 
planners of education should consider learner's behavioural changes as being dependent on their levels of cognition in terms of awareness, perception, and motivation, all which result into enthusiasm to learn. As a result of this, more efforts should be exerted on adequate provision of infrastructure in a manner that recognizes the number of students on school enrolment and possibly, the prospective ones. Findings in this study have shown that level of students' zeal for learning is determined by the quantity and quality of available infrastructure. As a result, availability and adequacy of physical infrastructure, well equipped libraries, with ICT and laboratories with modern machines are not just necessary if minimum standard is to be attained but also an essential part of a conducive learning environment. If facilities do affect the learning process and school administrators, planners and policymakers are not taking this into account, it may frustrate the outcome of the process. The outcomes are the broad effects achievable on the students. Such outcomes include students' knowledge, ability to appreciate and enjoy cultural activities, behave with social responsibility, participate in democratic politics and be productive members of the labour force. These outcomes cannot be achieved except the necessary infrastructure capable of motivating the learners is adequately put-inplace in order to arrive at quality university education that is beneficial to the learners and the society at large. Also, measures should be put in place by university administrators to ensure adequate maintenance of the available facilities and equipment to forestall deterioration and wastages.

\subsection{Conclusion}

Infrastructural factors such as classroom, library, laboratories, instructional gadget and office space are significant in the quality assurance of university education. Unfortunately, lecture rooms and office places are grossly inadequate and not convenient for proper positioning of modern electronic gadgets that will accommodate current curriculum and the globally acceptable mode of teaching and learning. If there is anything that the learners expect of universities, it is high quality teaching and learning characterized by factors such as quality teachers, quality learning materials and adequate infrastructure. This study shows that both the federal and state universities within this scope have no adequate infrastructure that are commensurate with the number of students on the institutions' enrolment and number of programmes. Surprisingly, facilities available in some universities are not modern and do not portray university status in any manner. If the quality of the infrastructure can be this low, then the quality of the staff and students who need them to work for the achievement of effective teaching and learning for quality outcome will be in doubt. 


\subsection{Way Forward}

Based on the findings of this study, the following suggestions were given as way forward to the identified infrastructural problems in the nation's university education:

- Government should wake up to her onus of adequate funding of education and provision of infrastructure that will benefit students and staff alike in the universities.

- The quality of university education must not be compromised by over enrolment, over-crowdedness and the multi campus system.

- Development of a high level of maintenance practice on the available facilities should be institutionalized. However, there is a need for the implementation of a direct quality assurance program to ensure that maintenance standards are met.

- Basic infrastructure like electricity, pipe-borne water, and road network should be improved upon. The constant erratic power outages in the universities call for immediate attention. It is recommended that each faculty has alternative source of power supply to ensure that faculty members are not delayed unnecessarily from carrying out their routine administrative and academic assignments. However, standards should be maintained in the provision so that "disturbing" power generators are not put in circulation.

- Promoting an institutional culture of quality and sincere self-analysis to guide the university administration, academic planners and policy implementers.

\section{References}

Adams, D. (1993). Defining educational quality. Improving educational quality project publication 1: Biennial report. Arlington, VA: Institute for International Research.

Adedipe, N. O. (2007). University quality assurance: Finding strategy and task allocation. Being paper presented at the workshop on tertiary education financing at the University of Lagos on April 23 - 24.

Adegbesan, S. O. (2011). Establishing quality assurance in Nigerian education system: Implication for educational managers. Educational Research and Reviews. Vol. 6(2), pp. 147-151

Ajayi, I. A. and Akindutire, I. O. (2007). The unresolved issues of quality assurance in Nigerian universities. Journal of Sociology and Education in Africa 6(1). 
Alele-Williams, G. (2004). Shaping a new and action for a more functional and qualitative education in Lagos State. A paper delivered at Excellence hotel on 6th July.

Benya, J. R. (2001). Lighting for Schools. Washington, D. C: National Clearinghouse for Educational Facilities. http://www.edfacilities.org/pubs/lighting.html.

Dahunsi, A. A. (2007). University Education in Nigeria: Challenge of its administration. Studies in Educational administration and planning, 3(1).

Ehiametalor, E. T. (2001). School facilities: Management practice in Nigeria. In N.A. Nwaguru, E. T. Ehiametalor, and M. A. Ogundu, M. Nwadiami (Eds), Current issues in educational management in Nigeria, 305-319. NAEAP Publication. Benin City: Ambik Press Ltd.

Ejiogu, A. M. (1997). Managing toward school effectiveness and efficiency in Nigeria. In Ejiogu, A. M \& Ajayi K. (Eds.) Emergent Issues in Nigeria Education. Lagos: Unilag Consult.

Federal Government of Nigeria (2004). National Policy on Education (Revised). Lagos: NERDC Press.

National Universities Commission (2004). Performance of the Federal University system in 2002. A report presented at the meeting convened by the honourable Minister of Education on Thursday, December 12.

Nwagwu, N. A. (2004). The organization and management of primary and secondary education in Nigeria in E. O. Fagbamiye, J. B. Babalola, M. Fabunmi and A. O. Ayeni (Eds.). Management of primary and secondary education in Nigeria, 17-26. NAEAP Publication, Ibadan, Awemark Industrial Printers.

Oderinde, B. (2004). Secondary education study in Lagos State. A report of the state of Secondary education in Lagos State. March.

Okebukola, P. O. (2010). Fifty years of higher education in Nigeria: Trends in quality assurance. A paper presented at the International Conference on the Contributions of Nigerian Universities to the 50th Independence Anniversary of Nigeria, September 27-29.

Okebukola, P. O. (2005). Partly cloudy university horizon: Promise of sunshine by private providers. Foundation day lecture, Bells University of Technology, Otta.

Oni, A. A. and Alade, I. A. (2010). Towards improving the status of higher education in Nigeria. The Online Journal of Academic Leadership, 8(3).

Osagie, R. O. (2003). Facilities and University development. In N.A. Nwaguru, E. T. Ehiametator, M. A. Ogunu and M. Nwadiani (Eds.). Current issues in educational management in Nigeria, 332-343. NAEAP Publication, Benin City, Ambik Press Ltd.

Oyebade, S. A., Oladipo, S. A. and Adetoro, J. A. (2007). Determinants and strategies for quality assurance in Nigerian university education. A Paper 
presented at the second regional conference on reform and revitalization in higher education. Organized by Higher Education Research and Policy Network (HERPNET) at IITA Ibadan, Nigeria. August 13- 16.

Salis E. (2002). Total quality management in education ( $3^{\text {rd }}$ ed.). London: Kogan Page Ltd.

Subair, S. O. (2011). Infrastructure and students' perceived motivation to learning in universities in South-Western Nigeria. In Alani, A. and Oni, S. (Eds.). Trends and Issues in Education in Nigeria. Ibadan: TriumphProvidential Publishers

Subair, S. O. (2008). Infrastructure, welfare services and students' perceived motivation to learning in universities in South-West Nigeria. An Unpublished PhD thesis, Department of Educational Administration, University of Lagos. 